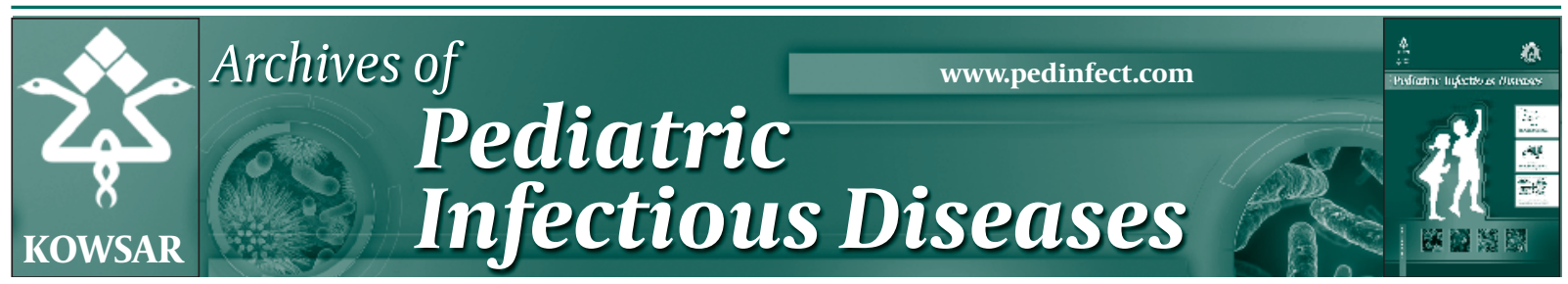

\title{
Cystic Fibrosis Needs Attention in Iran
}

\author{
Hossein Sadeghi ${ }^{1, *}$ \\ ${ }^{1}$ Division of Pediatric Pulmonology, Columbia University, New York, NY, USA \\ ${ }^{*}$ Corresponding author: Hossein Sadeghi, Division of Pediatric Pulmonology, Columbia University, New York, NY, USA. Tel: +1-2032765949, Fax:+1-2032764097, \\ E-mail:HSadeghi@stamhealth.org.
}

Keywords: Cystic Fibrosis; Iran

The purpose of this editorial is to raise awareness of the care of cystic fibrosis (CF) patients in Iran. The outlook for patients diagnosed with cystic fibrosis internationally has improved substantially in the past 30 years, but the same does not hold true for a child born with cystic fibrosis in Iran.

Numerous therapies such as antibiotics $(1,2)$, anti-inflammatory agents (3), mucolytics $(4,5)$, airway (6) and mucous (7) clearance, nutritional support (8), and cystic fibrosis transmembrane conductance regulator (CFTR) potentiators (9) have proven effective in select CF patients, and allowed the United States, Australia and Europe to make great strides in the treatment of CF. Other therapeutic approaches such as gene therapy have dealt with more difficulty than originally anticipated (10).

The barriers to accessing quality health care for CF patients in Iran are multifaceted including access to medication, implementation of recognized CF standard adopted guidelines by providers, and lack of early diagnosis (11), management and treatments of such patients across the country. These difficulties were compounded by lack of pediatric Pulmonology subspecialty until 2010 that would have been an advocate for this disease.
Throughout the world there are intensive efforts to find cure for patients with CF in the near future. CF patients in Iran can leap forward past decades of stagnation in their disease management and make the dream of cure into reality. This can be achieved through a systematic team approach with the goal of improving the life of CF patients and their families. This team effort can be initiated by education about the disease and training of team members to manage CF until a cure is found for all.

Cystic fibrosis is a systemic autosomal recessive heritable disorder. A defective gene on chromosome 7 produces a defective protein (CFTR) that results in decreased chloride secretion and hyperabsorption of sodium. This produces dehydrated mucous within the airway and thick secretions in the pancreatic ducts leading to pathogenic colonization and chronic infection in the respiratory tract and destruction of pancreatic ducts. Thereby, producing the clinical symptoms of cough, chronic respiratory symptoms and infection, recurrent exacerbations, malnutrition and failure to thrive.

Infection control measures (12) should be one of the early educational and quality improvement measures in the clinics and hospitals. Iran has improved substantially

Article type: Editorial; Received: 07 Apr 2013, Accepted: 20 Apr 2013; DOI: 10.5812.pedinfect.11672

-Implication for health policy/practice/research/medical education:

CF is considered as an important chronic pulmonary disease in children implementation of a guideline and clearing the weak point in treatment and diagnoses of this disease is an important aspect of view.

-Please cite this paper as:

Sadeghi H. Cystic Fibrosis Needs Attention in Iran. Arch Pediatr Infect Dis.2013;1(3):107-8. DOI: 10.5812.pedinfect.11672

Copyright ( 2 2013, Kowsar Corp.; Published by Kowsar Corp.

This is an Open Access article distributed under the terms of the Creative Commons Attribution License (http://creativecommons.org/licenses/by/3.0), which permits unrestricted use, distribution, and reproduction in any medium, provided the original work is properly cited. 
from a few years ago when CF patients were cohorted next to each other regardless of their age or bacterial colonization in their sputum cultures. Strict hand-hygiene measures should be implemented for health care providers. CF patients should be in a single room as inpatients away from other CF patients or those with viral infections.

CF patients should be educated on proper nutritional health (13). Pancreatic enzymes should be administered at the time of ingestion of food to improve absorption of fat and protein. Their administration should not be on a time schedule irrespective of dietary intake. Maintaining nutritional health improves lung function (14) and reduces the rate of infection and respiratory exacerbations (15).

Low socioeconomic status has been associated with worse health outcomes and increased mortality in CF $(16,17)$. Iranian CF patients may suffer both from financial constraints as well as shortage of medications that are not available due to the prevailing politico-economic constraints in the country.

One important step is establishment of Iranian CF registry to keep track of quality of care across the country. This editorial can serve as the first of many steps to recognize the need to establish nationalized guidelines for early diagnosis, management and treatment of cystic fibrosis in Iran.

\section{Authors' Contribution}

The article was prepared solely by the author.

\section{Financial Disclosure}

None.

\section{References}

1. Ramsey BW, Dorkin HL, Eisenberg JD, Gibson RL, Harwood IR, Kravitz RM, et al. Efficacy of aerosolized tobramycin in patients with cystic fibrosis. N Engl J Med.1993;328(24):1740-6.

2. Saiman L, Marshall BC, Mayer-Hamblett N, Burns JL, Quittner AL, Cibene DA, et al. Azithromycin in patients with cystic fibrosis chronically infected with Pseudomonas aeruginosa: a randomized controlled trial. JAMA. 2003;290(13):1749-56.

3. Konstan MW, Byard PJ, Hoppel CL, Davis PB. Effect of high- dose ibuprofen in patients with cystic fibrosis. $N$ Engl J Med 1995;332(13):848-54.

4. Fuchs HJ, Borowitz DS, Christiansen DH, Morris EM, Nash ML, Ramsey BW, et al. Effect of aerosolized recombinant human DNase on exacerbations of respiratory symptoms and on pulmonary function in patients with cystic fibrosis. The Pulmozyme Study Group. N Engl J Med.1994;331(10):637-42

5. Shah PL, Scott SF, Fuchs HJ, Geddes DM, Hodson ME. Medium term treatment of stable stage cystic fibrosis with recombinant human DNase I. Thorax. 1995;50(4):333-8.

6. Flume PA, Robinson KA, O'Sullivan BP, Finder JD, Vender RL, Willey-Courand DB, et al. Cystic fibrosis pulmonary guidelines: airway clearance therapies. Respir Care. 2009;54(4):522-37.

7. Elkins MR, Robinson M, Rose BR, Harbour C, Moriarty CP, Marks $\mathrm{GB}$, et al. A controlled trial of long-term inhaled hypertonic saline in patients with cystic fibrosis. N Engl J Med. 2006;354(3):22940.

8. Stallings VA, Stark LJ, Robinson KA, Feranchak AP, Quinton H. Evidence-based practice recommendations for nutrition-related management of children and adults with cystic fibrosis and pancreatic insufficiency: results of a systematic review. J Am Diet Assoc. 2008;108(5):832-9.

9. Accurso FJ, Rowe SM, Clancy JP, Boyle MP, Dunitz JM, Durie PR, et al. Effect of VX-770 in persons with cystic fibrosis and the G551DCFTR mutation. N Engl J Med. 2010;363(21):1991-2003.

10. Griesenbach U, Alton EW. Progress in gene and cell therapy for cystic fibrosis lung disease. Curr Pharm Des. 2012;18(5):642-62

11. LeGrys VA, Yankaskas JR, Quittell LM, Marshall BC, Mogayzel PJ, Jr. Diagnostic sweat testing: the Cystic Fibrosis Foundation guidelines. J Pediatr. 2007;151(1):85-9.

12. Saiman L, Siegel J. Infection control recommendations for patients with cystic fibrosis: microbiology, important pathogens, and infection control practices to prevent patient-topatient transmission. Infect Control Hosp Epidemiol. 2003;24(5 Suppl):S6-52.

13. Steinkamp G, Wiedemann B. Relationship between nutritional status and lung function in cystic fibrosis: cross sectional and longitudinal analyses from the German CF quality assurance (CFQA) project. Thorax. 2002;57(7):596-601.

14. George PM, Banya W, Pareek N, Bilton D, Cullinan P, Hodson ME, et al. Improved survival at low lung function in cystic fibrosis cohort study from 1990 to 2007. BMJ. 2011;342:d1008.

15. Corey M, Farewell V. Determinants of mortality from cystic fibrosis in Canada, 1970-1989. Am J Epidemiol. 1996;143(10):1007-17.

16. Curtis JR, Burke W, Kassner AW, Aitken ML. Absence of health insurance is associated with decreased life expectancy in patients with cystic fibrosis. Am J Respir Crit Care Med.1997;155(6):1921-4.

17. Schechter MS, Shelton BJ, Margolis PA, Fitzsimmons SC. The association of socioeconomic status with outcomes in cystic fibrosis patients in the United States. Am J Respir Crit Care Med. 2001;163(6):1331-7. 